Idarotuna, Vol. 1, No. 2. April 2019

\title{
Urgensi Dakwah Bil Hikmah pada Generasi Millenial
}

\author{
Nur Alhidayatillah \\ Fakultas Dakwah dan Komunikasi,UIN Suska Riau, \\ Jl. HR Soebrantas Km 15 Simpangbaru, Tampan, Pekanbaru 50275 \\ Email: nuralhidayatillah@uin-suska.ac.id
}

\begin{abstract}
Abstrak
Generasi millenial yang kerap menggunakan teknologi dan informasi dalam segala aktivitasnya menjadi pusat perhatian saat ini. Generasi millenial dianggap prontal oleh generasi terdahulu karena dianggap merombak tatanan-tananan kehidupan masyarakat yang sudah dianggap baik dan harmonis selama ini. Kemajuan teknologi informasi dan komunikasi yang teradopsi dari kemajuan ilmu pengetahuan dan teknologi mengakibatkan terjadinya pergeseran nilai, baik bersifat positif maupun negatif. Nilai-nilai positif bisa dilihat melalui perpaduan kebudayaan Islam dan kebudayaan Barat yang menjadikan Islam semakin kaya akan nilai-nilai kebudayaan melalui pembuktian sains dan teknologi. Sedangkan dampak negatif lebih kepada peniruan cara hidup yang dianggap tidak sesuai dengan budaya ketimuran. Melihat banyaknya fenomena generasi millenial yang mengkhawatirkan maka diperlukan adanya kontrol sosial. Salah satu control sosial yaitu melalui kegiatan dakwah dengan metode bil hikmah. Kurangnya figur yang bisa dijadikan teladan melatarbelakangi metode ini untuk bisa diterapkan. Pemanfaatan media-media informasi bisa digunakan sebagai sarana dakwah karena generasi millenial kerap menggunakannya.
\end{abstract}

Kata kunci: dakwah, metode bil-hikmah, generasi millenial 


\section{Pendahuluan}

Kehidupan manusia modern tidak lepas dari penggunaan mediamedia elektronik, jaringan, mesin, dan segala macam atribut revolusi industri 4.0 yang sedang booming saat ini. Aktivitas kehidupan manusia sangat bergantung kepada mediamedia berbasis jaringan dan teknologi. Kemajuan yang terjadi tidak dapat disangkal menimbulkan dampak negatif berupa merosotnya nilai-nilai moralitas sebagian umat Islam. Mereka yang cenderung menerima dan mengadopsi nilainilai budaya Barat tanpa melakukan filtrasi terlebih dahulu. Salah satu dampak yang dirasakan sekarang seperti yang digambarkan oleh John Naisbit dalam Mega Trend 2000. Ia menyebutkan kecenderungan masyarakat saat ini dapat dilihat dalam 3F: fun (hiburan), food (makanan), and fashion (pakaian). Lain halnya dengan Jalaluddin Rahmat yang meramalkan dalam 5F: faith, fear, acts, fiction, dan formulatilation. ${ }^{1}$

Tak ayal lagi, generasi milenial yang kerap menggunakan jaringan dan teknologi dalam segala aktivitasnya menjadi pusat perhatian saat ini, terutama bagi generasi sebelumnya. Generasi millenial dianggap prontal oleh generasi terdahulu karena dianggap merombak tatanan-tananan kehidupan masyarakat yang sudah dianggap baik dan harmonis selama ini. Kemajuan teknologi informasi dan komunikasi yang teradopsi dari kemajuan ilmu pengetahuan dan teknologi mengakibatkan terjadinya

1 Jalaluddin Rahmat, Islam Aktual, (Bandung: Mizan, 1996), Cet. IX, h. 71. pergeseran nilai, baik bersifat positif maupun negatif. Nilai-nilai positif bisa dilihat melalui perpaduan kebudayaan Islam dan kebudayaan Barat yang menjadikan Islam semakin kaya akan nilai-nilai kebudayaan melalui pembuktian sains dan teknologi.

Dibalik semua anggapan yang melekat pada generasi millenial terdapat juga berbagai keistimewaan yang mereka bawa. Cara kerja yang cerdas dalam waktu yang singkat menjadi kebanggaan mereka. Walaupun kebanyakan semua aktivitas yang mereka lakukan tidak bisa lepas aplikasi-aplikasi yang mereka gandrungi. Aplikasi yang menyediakan berbagai kebutuhan, bahkan bisa menjadi sumber penghasilan. Misalnya saja dua youtuber muda Indonesia yang sangat digandrungi saat ini yaitu Atta Halilintar dan Ria Ricis. Keduanya memanfaatkan media sosial sebagai media aktualisasi diri dan menghasilkan pundi-pundi rupiah dengan jumlah yang sangat fantastis. Bahkan, bisa membuka peluang kerja bagi mereka yang ada disekitarnya. Tentu saja, kondisi ini membuat banyak orang tergiur untuk meniru apa yang dilakukan oleh kedua generasi muda ini.

Sebaliknya, tidak ada keuntungan yang tidak menunjukkan cacat. Buktinya, tidak sedikit generasi millenial yang terbawa arus dalam artian terlena, bahkan terperangkap oleh kemudahankemudahan yang ada. Kehadiran alat-alat canggih berbasis informasi dan teknologi membuat mereka larut dalam dunia barunya. Acuh terhadap lingkungan, tercabut dari akar kebudayaannya, kecanduan game 
online, hedonisme, terlibat kejahatan online, peniruan berbagai aksi yang kurang baik, dan lain sebagainya.

Contoh, tiga hari ini, publik dihebohkan dengan berita audrey, siswa SMP yang berseteru dengan siswa SMA di Kalimantan Barat. Bermula dari perseteruan melalui grup Whatsapp (WA) hingga berlanjut menjadi aksi brutal berupa penganiayaan kepada audrey sungguh disayangkan. Saking hebohnya muncul tagar \#justiceaudrey yang sangat viral. $^{2}$ Berbagai simpati dan emptipun muncul sebagai bentuk dukungan terhadap audrey dan penolakan terhadap bullying dan kekerasan. Dunia pendidikan Indonesia kembali disoroti dengan munculnya kasus ini. Kemudian beberapa hari berselang muncul pula tagar bandingan \#audreyjugabersalah yang mengatakan bukan hanya pelaku yang bersalah tetapi audrey juga. Berbagai statmen bermunculan terkait kasus ini sehingga mengakibatkan kebenaran berita yang tersaji mendatangkan berbagai pertanyaan dan pernyataan baru. Apalagi media-media sosial yang sangat akrab dengan kata "netizen maha benar", seolah semua orang bebas mengomentari segala hal terkait dengan urusan orang lain.

Kisah audrey dan siswa SMA ini merupakan salah satu bentuk dampak dari penggunaan media informasi yang kurang arif sehingga bukannya bermanfaat untuk ajang

${ }^{2} \mathrm{http}: / /$ pontianak.tribunnews.com/ta g/justiceaudrey?url=2019/04/11/benarkahterjadi-penusukan-alat-kelamin-di-kasusaudrey-pontianak-fakta-fakta-inimenjawabnya, diunduh tanggal 13 April 2019, 04.06 WIB silaturahim malah menjadi sumber permasalahan. Media informasi yang didukung oleh kemajuan teknologi membuat manusia bisa mengakses apa saja sehingga dibutuhkan kearifan dalam penggunaannya. Semua hal tersaji dengan nyata dan kearifan pengguna yang dibutuhkan disini untuk memfilter dan mengkonsumsi bacaan, tontonan, permainan yang sesuai atau tidak, baik atau buruk untuk diterima kemudian dilakukan. Jika semuanya diterima tanpa ada penyaringan ini yang akan menyebabkan kesalahankesalahan baru dalam menyikapi kondisi tertentu. Apalagi bagi anakanak atau remaja yang belum mampu memilih mana yang sesuai dengan usia mereka. Remaja belum bisa membedakan mana yang trend mana yang modern, bagi mereka semuanya sama saja, apalagi jika dilakukan oleh orang kebanyakan. Kebiasaan meniru apa yang mereka liat dan dengar seringkali melahirkan kesalahan-kesalahn dalam melakukan sesuatu.

Keuntungan dan bahaya yang muncul dari kecanggihan informasi dan teknologi bagaikan dua sisi koin yang tidak dapat dipisahkan. Keduanya saling menyatu dan berkaitan, disatu sisi positif, sedangkan sisi lainnya negatif. Oleh karena itu, semua orang diharapkan mampu memfilter semua hal yang diterimanya. Berdasarkan kondisi ini, muncul ide bagi penulis untuk membahas lebih lanjut dengan memfokuskan kajian pada urgensi metode dakwah bil hikmah pada generasi millenial. Generasi millenial membutuhkan hikmah agar tidak mudah meniru sesuatu tanpa tahu mengapa mereka melakukannya. 


\section{Pengertian dakwah}

Dalam bahasa Arab kata da'wah disebut mashdar, da'wah berarti panggilan, seruan atau ajakan. Adapun dalam bentuk kata kerja ( $f i i l$ ) berasal dari kata $d a^{\prime} a, y a d^{\prime} u$, da'watan yang berarti memanggil, menyeru atau mengajak. ${ }^{3}$ Istilah ini sering diberi arti yang sama dengan istilah-istilah tabligh, amr ma'ruf dan nahi munkar, mau'idzoh hasanah, tabsyir, indzhar, wasiyah, tarbiyah, ta'lim. Adapun menurut para ahli pengertian dakwah sebagai berikut:

1. Dakwah adalah upaya kegiatan mengajak atau menyeru umat manusia agar berada di jalan Allah (sistem Islami) yang sesuai dengan fitrah dan kehanifannya secara integral, baik melalui kegiatan lisan dan tulisan atau kegiatan nalar dan perbuatan, sebagai upaya pengejawantahan nilai-nilai kebaikan dan kebenaran spiritual yang universal sesuai dengan dasar Islam. ${ }^{4}$

2. Dakwah menurut Jalaluddin Rahmat adalah fenomena sosial yang dirangsang keberadaannya oleh nash-nash agama Islam. Fakta-fakta sosial tersebut dapat dikaji secara empiris terutama pada aspek proses penyampaian dakwah serta internalisasi nilai agama bagi penerima dakwah". 5

3 Wahidin Saputara, Pengantar Ilmu Dakwah, (Jakarta.: Rajawali Press, 2011), h. 1

4 Asep Muhyidin, Dakwah Dalam Perspektif Al-Qura'an: Studi Kritis Atas Visi, Misi dan Wawasan, (Bandung: Pustaka Setia, 2002), h. 19

5 Jalaluddin Rahmat. Ilmu Dakwah dan Kaitannya Dengan Ilmu-Ilmu Lain, (Semarang, Seminar, 1990), h. 4
3. Dakwah adalah segala aktifitas yang dilakukan oleh mukmin sesuai dengan kemampuan yang dimilikinya. Bertujuan menjadikan seluruh umat manusia beragama Islam dengan baik disertai akhlak yang mulia agar mereka memperoleh sa'adah masa kini dan masa yang akan datang. Dakwah dapat dipahami sebagai suatu sistem dalam mengupayakan aktifitas mencapai sasarannya dengan tepat terkait dengan berbagai komponen dakwah itu sendiri. ${ }^{6}$

4. Dakwah adalah proses transformasi ajaran dan nilai-nilai Islam dari seorang atau sekelompok da'i kepada seorang atau sekelompok mad'u dengan tujuan agar seseorang atau sekelompok orang yang menerima transformasi ajaran dan nilai-nilai Islam itu terjadi pencerahan iman dan juga perbaikan sikap serta prilaku yang Islami. ${ }^{7}$

Selain pendapat di atas dakwah dapat juga dimaknai dengan upaya menciptakan kondisi yang kondusif untuk terjadinya perubahan pikiran, keyakinan, sikap dan prilaku ke arah pikiran, keyakinan, sikap dan prilaku yang lebih Islami. Dengan kata lain, melalui kegiatan dakwah seseorang atau sekelompok orang akan berubah pikiran, keyakinan, sikap dan prilakunya ke arah yang lebih positif yaitu ke arah yang sesuai dengan

${ }^{6}$ Salmadanis, Standar Kompetensi Pelaku Dakwah, (Sumatra Barat: Imam Bonjol Pres, 2014). h. 13

7 Syulrianto, Dakwah Kultural: Kasus Penyebaran Islam di Jawa, Fakultas Dakwah IAIN Sunan Kalijaga, (Jurnal Dakwah No, 4 Januari-Juni 2002), h. 118 
ajaran atau nilai-nilai yang ada dalam Islam.

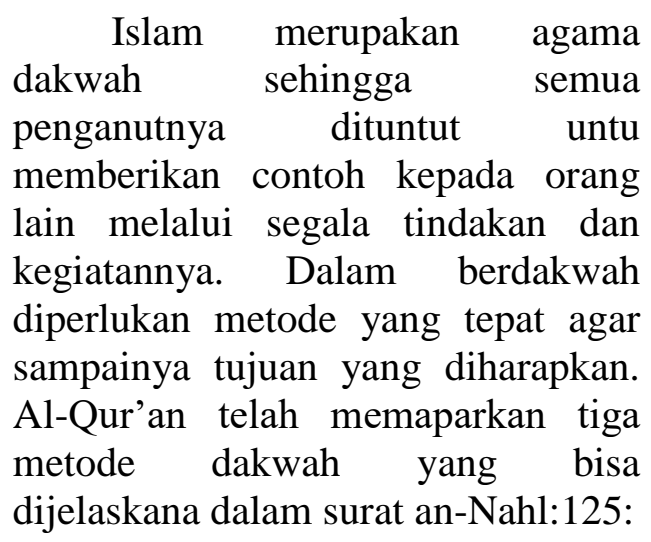

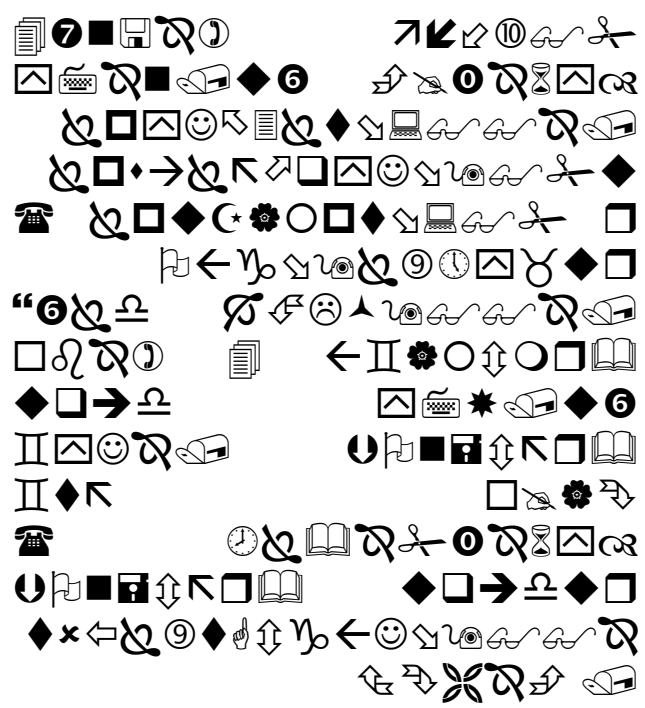

Artinya:Serulah (manusia) kepada jalan Tuhanmu dengan hikmah dan pelajaran yang baik dan banahlah mereka dengan cara yang baik. Sesungguhnya Tuhanmu Dialah yang lebih mengetahui tentang siapa yang tersesat dan jalan-Nya dan Dialah yang lebih mengetahui orang-orang yang mendapat petunjuk. (QS. An-Nahl (16): 125).

Ayat ini menjelaskan tiga metode dakwah yang bisa digunakan yaitu bil hikmah, mauidzatil hasanah, dan mujadalah. Dari ketiga metode ini penulis memfokuskan kajian pada metode dakwah bil hikmah karena pendekatan dakwah bil hikmah mempunyai daya tarik yang terbilang unik dengan caranya yang lembut dan santun. Abdullah mengatakan da'i masa kini harus mempersiapkan element atau perangkat dakwah yang meliputi tiga kompetensi, yaitu:

1. Kompetensi substantif

2. Kompetensi metodologis

3. Penguasaan teknologi komunikasi

Kompetensi substantif
merupakan penguasaan ilmu pengetahuan. Kompetensi metodologis merupakan kemampuan membuat peta dakwah, merencanakan dan mengoperasionalnya. Sedangkan kompetensi dalam bidang penguasaan teknologi komunikasi modern, menyangkut kemampuan dalam penggunaan teknologi sebagai media dakwah. ${ }^{8}$

Dakwah Islam dalam penerapan atau aktualisasinya sebenarnya merupakan proses kebudayaan. Proses pembudayaan maksudnya yaitu memasyarakatkan dan menerapkan nilai-nilai Islam dalam kehidupan secara berproses melalui cara-cara bil-hikmah (keilmuan dan kearifan), wa almau'idhat al-hasanah (pendidikan, edukasi), wa jadil-hum bilatihiya ahsan (diskusi, kajian ilmiah, dialogis) yang utama. ${ }^{9}$ Ketiga cara

8 Abdullah, Ilmu Dakwah, Kajian Ontologi, Epistimologi, Aksiologi dan Aplikasi Dakwah, (Bandung: Citapustaka Media, 2015), h. 177

${ }^{9}$ Ibid 
tersebut dapat dikembangkan lagi ke dalam ide-ide kreatif yang sesuai dengan kebutuhan manusia saat ini. Islam sudah mengatur setiap jalan yang bisa digunakan oleh manusia sesuai dengan kebutuhannya.

\section{Metode dakwah bil hikmah}

Kata hikmah mempunyai beberapa makna yang perlu dikaji agar dapat diambil makna yang sesungguhnya. Dalam bahasa Indonesia, kata "hikmah" diartikan sebagai: 1) kebijaksanaan (dari Allah) 2) kesaktian, ${ }^{10}$ sehingga orang yang memiliki hikmah adalah orang yang memiliki kebijaksanaan atau kesaktian, sedangkan "kata-kata hikmah" adalah kata-kata yang mengandung kebijaksanaan atau kesaktian. Al-Alūsī mengemukakan dalam tafsirnya bahwa yang dimaksud dengan hikmah adalah meletakkan sesuatu pada tempatnya, atau pemahaman terhadap agama, baik yang bersumber dari kitab Alquran maupun dari hadis. Lebih lanjut ia mengemukakan bahwa hikmah itu terbagi dua, ada yang berbentuk teoretis dan ada yang berbentuk praktis. ${ }^{11}$

Ibnu Āsyūr berpendapat bahwa yang disebut dengan hikmah adalah penyempurnaan ilmu pengetahuan dan pengamalan sesuai

\footnotetext{
10 Departemen Pendidikan dan Kebudayaan, Kamus Besar Bahasa Indonesia (Jakarta: Balai Pustaka, 1996), h. 351.

11 Syihāb al-Dīn Said Maḥmūd alAlūsī al-Baghdādī, Rūh al-Ma'ān̄̄ fī Tafsīr al-Qur'ān al-Aẓ̄̄m wa al-Sab' al-Maṡān̄̄ (Bairut: Dār al-Kutub al-Ilmiyah, 2001), h. 285.
}

dengan ilmu yang dimiliki. ${ }^{12}$ Ibnu Rajab memberikan komentar tentang makna hikmah yang mencakup semua makna. Ia mengatakan: 'Yang dimaksud dengan hikmah adalah segala yang menghalangi dari kebodohan dan mencegah dari yang kejelekan. ${ }^{13}$

Kata hikmah berasal dari akar kata "hakama", kata yang menggunakan huruf hā', kāf dan mīm yang oleh Ibn Fāris diartikan dengan المنع " menghalangi” seperti hakam yang berarti menghalangi terjadinya penganiayaan, kendali bagi hewan disebut hakama yang berarti menghalangi hewan untuk mengarah kepada hal yang tidak diinginkan, atau liar. ${ }^{14}$ Kata hikmah dalam berbagai bentuknya dalam Alqur'an terulang dalam 210 ayat. Kata kerja dengan pola hakama sebanyak 1 kali, hukman sebanyak 11 kali, hukm sebanyak 53kali, yahkumu sebanyak 23 kali, ahkām sebanyak 3 kali, hākim sebanyak 81 kali, ${ }^{15}$ sedangkan kata-kata hikmah yang menjadi objek pembahasan dalam tulisan ini sebanyak 20 kali pada 19 ayat dan 12 surah. Kata hikmah mempunyai makna yang

12 Ibnu Asyūr, al-Tahrīr wa alTanwīr, Juz 2 (Bairut: Dār al-Fikr, t.th.), h.461

13 Zain al-Dīn Abī al-Faraj ibn Rajāb al-Hambalī, Fath al-Bāri' bi Syarh alBukhāri, Jilid 1 (Madinah : Maktabat alGhuraba), h. 166.

${ }^{14}$ Abū al-Husain Aḥmad ibn Fāris ibn Zakariyā, Mu'jam al-Muqāyis fĩ alLughah, ( Cet. II: Bairut: Dār al-Fikr li alTarbiyah wa al-Nasyr wa al-Tauzī,1998), h. 277.

15 Muhammad Fuād 'Abd al-Bāqī, Mu’jam Mufahras li al-Fāz al-Qur'ān alKarīm (Bairut: Dār al-Fikr, 1992), h. 269273. 
berbeda-beda, menurut al-Rāzî̀ ${ }^{16}$, kata al-hikmah memiliki empat pengertian, yaitu : 1). Mawāiz alQur'ān, 2). Al-Fahm wa al-'Ilm' 3). kenabian,dan 4). Pemahaman yang mendalam terhadap Alquran. ${ }^{17}$

Kata "hikmah" dalam AlQuran disebutkan sebanyak 20 kali, baik dalam nakiroh maupun ma'rifat. Bentuk masdarnya adalah "hukuman" yang diartikan secara makna aslinya yaitu mencegah. Jika dikaitkan dengan hukum berarti mencegah dari kedzaliman, dan jika dikaitkan dengan dakwah maka berarti menghindari hal-hal yang kurang relevan dalam melaksanakan tugas dakwah. Menurut al-Ashma'i adal mula didirikanhukuman (pemerintahan) ialah untuk mencegah manusia dari perbuatan zalim. $^{18}$

Adapun metode dakwah bil hikmah yang dilakukan Nabi Muhammad, dalam QS. Al-Nahl, 16:125, yaitu memeberikan teladan yang terbaik dalam sikap dan perilaku, dengan sesalu sopan santun kepada siapapun. Hal ini kemudian diistilahkan dengan akhlaqulkharimah. Beliau mendapat predikat dari langit "uswatun hasanah" (baca QS. Al-Ahzab, 33:21) yang bermakna teladan terbaik dan terpuji. Dengan metode tersebut, puluhan sampai ribuan orang Arab yang

\footnotetext{
16 Muhammad Fuād 'Abd al-Bāqī, Mu'jam Mufahras li al-Fāz al-Qur'ān al-

Karīm (Bairut: Dār al-Fikr, 1992), h. 269-273.

17 Muhyiddin Tahir, Hikmah dalam Perspekt Al-Qur'an Hunafa: Jurnal Studia Islamika, PPs UIN Alauddin Makassar, Jl. Sultan Alauddin 23 Makassar, h. 89

18 Wahidin, Saputra, Pengantar Ilmu Dakwah, (Jakarta: Raja Gerafindo Persada), 2012. h. 224
}

tertarik terhadap ajaran Islam, yang kemudian mengucapkan syahadatain (pengakuan terhadap Allah dan Rasul-Nya, Muhammad SAW). ${ }^{19}$

Hikmah merupakan suatu term karakteristik metode dakwah sebagaimana yang termaktub dalam QS. An Nahl ayat 125. Ayat tersebut mengisyaratkan petingnya hikmah untuk menjadi sifat dari metode dakwah dan betapa pentingnya dakwah mengikuti langkah-langkah yang mengandung hikmah. Ayat tersebut seolah-olah menunjukkan metode dakwah praktis kepada para da'i yang mengandung arti mengajak manusia ke jalan yang benar dan mengajak manusia untuk menerima dan mengikuti petunjuk agama dan kaidah yang benar. Ayat tersebut juga mengisyaratkan bahwa mengajak manusia untuk menerima dan mengikuti petunjuk agama dan akidah yang benar. Ayat tersebut juga mengisyaratkan bahwa mengajak manusia kepada hakikat yang murni dan apa adanya tidak mungkin dilakukan tanpa melalui pendahuluan atau mmepertimbangkan iklim dan medan kerja yang sedang dihadapi. ${ }^{20}$

Dakwah al-hikmah dapat diartikan sebagai kegiatan penyeruan atau pengajakan dengan cara yang bijak, filosofis argumentatif, penuh kesabaran dan ketabahan, sesuai dengan risalah nubuwwah dan ajaran al-Qur'an. Dakwah al-hikmah

${ }^{19}$ Asep Shaifuddin, Sheh Sulhawi Rubba, Fikih Ibadah Safari ke Baitullah, (Surabaya: Garisi, 2011), h. 27

20 Hasan Bastomi, Dakwah Bil Hikmah Sebagai Pola Pengembangan Sosial Keagamaan Masyarakat, Jurnal Ilmu Dakwah, Vol. 36(2) 2016 Eissn 2581-236x, h. 349 
dikenal sebagai dakwah yang bijak, selalu memperhatikan suasana, situasi, dan kondisi mad'u. Selalu melihat keadaan mad'u seperti tingkat pendidikan, usia, suasana psikologis, kultural mad'u, dan lain sebagainya. Dakwah al-hikmah menurut Sayid Qutb harus memperhatikan tiga hal, yaitu:

a. Keadaan dan situasi orang-orang yang didakwahi.

b. Kadar atau ukuran materi dakwah yang disampaikan harus sesuai dengan tingkat pemahaman mad'u.

c. Metode penyampaian materi dakwah harus dibuat sedemikian rupa agar menarik perhatian mad'u. $^{21}$

Da'i yang menerapkan metode al-hikamah dalam kegiatan dakwah tentu telah mengenal terlebih dahulu keadaan mad'unya. Kesesuaian metode dakwah dengan mad'u sangat mempengaruhi sampai atau tidaknya pesan dakwah. dakwah dikatakan berhasil apabila pesan yang disampaikan dimengerti oleh mad'u. Didalam buku al-hikmah karangan Mahmud Muhammad AlKhazandar disimpulkan bahwa hikmah diartikan dintaranya sebagai berikut: ${ }^{22}$

1. Memahami alqur'an,mengenal kebenaran dan mengamalkannya.

2. Meletakkan sesuatu pada tempatnya

3. Selalu sederhana, berusaha memahami sebab, dan meletakkan segala perkara sesuai porsinya.

\footnotetext{
${ }^{21}$ Asep Muhyidin, op.cit., h. 80

${ }^{22}$ Mahmud Muhammad Al-

Khazandar, alhikmah, (terj) mohammad iqbal alghazali, isalm house.com, 2009/1430.
}

Adapun beberapa cara agar seseorang memperoleh hikmah menurut Mahmud Muhammad AlKhazandar diantaranya yaitu:

1. Memahami agama

2. Mengambil faedah dari pengalaman

3. Belajar dari kesalahan

4. Waspada agar tidak terjerumus dalam kesalahan

Mahmud Muhammad AlKhazandar mengatakan bahwa salah satu bentuk syukur terhadap nikmah hikmah yang diperoleh adalah dengan cara mengajarkannya kepada sesama manusia. Bersungguhsungguh untuk mencapai kebenaran termasuk hikmah yang tertinggi. Kebenaran yang sesungguhnya merupakan sesuatu yang sangat berharga dan dicintai oleh semua orang.

\section{Mengenal Generasi millenial}

Milenial juga dikenal sebagai Generasi Y. Para ahli dan peneliti biasanya menggunakan awal 1980-an sebagai awal kelahiran kelompok ini dan pertengahan tahun 1990-an hingga awal 2000-an sebagai akhir kelahiran. Kaum Millennial adalah mereka generasi muda yang terlahir antara tahun 1980an sampai 2000. Kaum Millennial terlahir dimana dunia modern dan teknologi canggih diperkenalkan publik.

Generasi

millennials memiliki ciri khas tersendiri yaitu, mereka lahir pada saat TV berwarna, handphone juga internet sudah diperkenalkan. Dampaknya, generasi ini sangat mahir dalam penggunaan teknologi. Di Indonesia sendiri dari jumlah 255 juta penduduk yang telah tercatat, terdapat 81 juta merupakan generasi millenials atau berusia 17 - 
37 tahun. Hal ini berarti Indonesia memiliki banyak kesempatan untuk membangun negaranya. Tapi, kemanakah mereka pergi? Apakah mereka bersembunyi? Sungguh tidak, jika kita melihat ke dunia sosial media, generasi millennials sangat mendominasi jika dibandingkan dengan generasi $\mathrm{X}$. Dengan kemampuannya di dunia teknologi dan sarana yang ada, generasi millenials belum banyak yang sadar akan kesempatan dan peluang di depan mereka.

$$
\text { Generasi }
$$

millennials

cenderung lebih tidak peduli terhadap keadaan sosial di sekitar mereka seperti dunia politik ataupun perkembangan ekonomi Indonesia. Kebanyakan dari generasi millenials hanya peduli untuk membanggakan pola hidup kebebasan dan hedonisme. Memiliki visi yang tidak realistis dan terlalu idealistis, yang penting bisa gaya. $^{23}$ Generasi millennial dianggap sebagai pembawa nilai-nilai negatif karena pengaruh yang dikonsumsi datang dari luar. Generasi millennial sangat terbuka dengan teknologi. Misal sederhana semua rumah mempunyai televisi, bahkan lebih dari satu. Dalam satu rumah memiliki channel favorit masing-masing sehingga bisa mempengaruhi sikap keseharian setiap individu. Setiap orang juga mempunyai smartphone dengan segala fitur terbaru yang ditawarkan. Facebook, youtube, twiter, instagram, whatshap dan lain sebagainya merupakan media yang paling banyak digunakan oleh generasi millennial.

${ }^{23} \mathrm{http}: / /$ rumahmillennials.com/siapa -itu-generasi-millenials/\#.XK9HW0gxXMw, diunduh 11 April 2019.

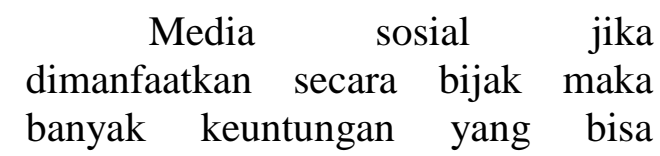
diperoleh bagi penggunanya. Melalui aplikasi-aplikasi yang ditawarkan, manusia saat ini dipermudah dalam proses komunikasi. Komunikasi tidak lagi tergantung kepada jarak tempuh dan waktu, dan biayanya lebih murah. Selain dampak negatif yang ditimbulkan, media sosial juga bisa dijadikan media pembelajaran, misalnya pemanfaatan vidio-vidio terkait materi yang diajarkan bisa kita dapatkan melalui aplikasiaplikasi yang ditawarkan. Beragam tutorial tentang pembelajaran, pembangunan, keterampilan juga tersedia melalui aplikasi-aplikasi yang tersedia.

Penggunaan media-media sosial yang hampir 24 jam dinikmati tidak hanya menyuguhkan informasi yang akurat. Banyak juga modusmodus kejahatan, penipuan yang digencarkan oleh oknum-oknum yang tidak bertanggung jawab. Penyebaran informasi bohong (hoaks), vidio-vidio yang tidak layak ditonton, penyebaran paham yang meresahkan masyarakat menjadi masalah sosial yang sulit untuk ditangani secara nyata. Selain itu, batas pengguna aplikasi-aplikasi tersebut tidak sepenuhnya terkontrol sehingga anak-anak dibawah umur telah melihat aksi yang seharusnya tidak mereka lihat. Kondisi seperti ini hampir meliputi setiap aktivitas yang terjadi di dunia maya. Akhirnya, mental-mental manusia saat ini secara perlahan mengalami perubahan, baik secara cepat maupun lambat.

Nilai-nilai sosial yang dulu sangat dielu-elukan seakan sudah 
hilang entah ke mana. Adat istiadat yang menjadi kontrol sosial seakan telah ditinggalkan oleh masyarakat muda. Mereka lebih mengedepankan rasionalisme dan egoisme dalam menyikapi sesuatu. Ketika paham mereka tidak sampai maka emosi yang akan mencuat kepermukaan. Kemarahan, makian, cercaan, aksi brutal menjadi tontonan yang lumrah saat ini. Paling parah ketika nilainilai keislaman yang selama ini menjadi kebanggaan umat Islam perlahan diracuni oleh pemikiranpemikiran yang bertujuan menyesatkan umat. Kata-kata modern dijadikan sebagai dalih sedangkan agama dipandang sebagai sesuatu yang kolot alias ketinggalan zaman. Modern diakui ketika manusia saat ini mampu hidup seperti orang barat dalam segala aspek kehidupannya. Sesuatu yang modern diakui jika mampu bersikap seperti yang dilakukan orang banyak, tidak lagi berdasarkan nilai agama atau nilai adat istiadat.

\section{Pentingnya dakwah bil hikmah bagi generasi millenial}

Kegiatan dakwah yang menarik selalu ditunggu oleh masyarakat. Dakwah masa kini tidak bisa dilakukan secara konvensional saja tetapi harus diperbaharui sesuai dengan karakter manusia saat ini. Hanya saja ketika kebebasan bereksplorasi dilakukan terlalu bebas ini menjadi PR lagi. Kemudahan mengakses berbagai konten kapan saja dan dimana saja kadang seperti dua sisi mata uang. Selain manfaat yang diperoleh, dampak negatifpun semakin marak saat ini. Yang menjadi pokok permasalahannya yaitu ketidakmampuan seseorang untuk memfilter apa yang baik dan yang tidak layak untuk dilakukan.

Menyikapi fenomena diatas maka diperlukan dakwah yang bisa diterima oleh semua kalangan tanpa merasa diinterpensi. Salah satu metode yang bisa dilakukan adalah metode bil hikmah. Dakwah bil hikmah yang dikenal dengan ciri khasnya yang lemah lembut, sopan , santun, caranya yang halus mempunyai daya tarik tersendiri dibanding metode dakwah yang lain. Banyaknya konten-konten dakwah yang tersebar di media-media sosial mempunyai berbagai metode dakwah yang bisa dipilih sesuai dengan kebutuhan penikmatnya.

Pendekatan agama atau dakwah terhadap generasi millennial juga harus dilakukan melalui pemanfaatan media-media komunikasi karena pengguna terbanyak adalah generasi millennial. Dakwah melalui pemanfaatan media komunikasi dan teknologi akan lebih mudah mencapai sasaran karena beda generasi beda pula cara pendekatan yang digunakan. Saat ini sudah hadir da'i-da'i yang mempunyai ciri khas tersendiri, mulai dari materi, style, retorika, performa, dan lain sebagainya. Generasi millennial sudah diberikan pilihan dari yang seperti apa yang akan mereka cari, style seperti apa yang akan mereka ikuti, materi apa yang mereka butuhkan, semua ini sudah bisa mereka dapatkan melalui situs-situs yang tersedia. Kapan waktunya, berapa lama, di mana, semuanya sudah bisa diatur oleh generasi millennial karena semua pilihan ini sudah tersedia. Berbeda dengan masa dulu yang segala aktivitas harus dilakukan secara kasat mata, diwaktu 
dan tempat yang sama. Jika tidak mengikuti sebuah kegiatan secara langsung maka akan ketinggalan, hanya akan mendapatkan berita atau sekedar cerita dari orang saja.

Salah satu tawaran metode dakwah yang diberikan yaitu bil hikmah dengan memberikan contoh tauladan yang baik, bahasa yang sopan, sikap yang santun dan lemah lembut, menunjukkan rassa saling menyayangi, berempati, peduli, menebarkan benih-bih kasih sayang kepada semua makhluk tuhan. Misalnya saja salah satu da'i kondang tanah air Abdullah Gymnastiar atau yang lebih dikenal dengan nama Aa' Gym merupakan salah satu sosok yang begitu kharismatik dengan metode dakwah bil hikmahnya. Aa' Gym pengasuh pondok pesantren darul tauhid di Bandung.

Aa' Gym dikenal dengan bahasanya yang lembut, sikapnya yang santun, dan penghargaannya terhadap orang lain yang begitu tinggi menjadi ciri khas yang melekat pada dirinya. Dapat disaksikan dibeberapa program televisi betapa Aa Gym memberikan contoh secara langsung bahwa amarah tidak akan menyelesaikan sebuah persoalan. Aa' Gym mengedepankan hati atau manajemen qalbu yang sangat melekat pada dirinya. Pendekatan dakwah bil hikmah Aa' gym lebih mengutamakan bagaimana manusia menjaga hati agar selalu bersih dari segala bentuk noda yang akan mengotorinya.

Diantara gambaran kebijaksanaan dalam berdakwah adalah memperhatikan kondisi audiens, kesesuaian materi dengan tingkat pemahan audiens, waktu penyampaian yang pas sehingga pesan dari dakwah yang disampaikan bisa tercapai. Untuk mencapai hasil yang maksimal dakwah bil hikmah harus dilakukan secara konsisten atau isiqamah karena hikmah tanpa istiqamah sama seperti kemunafikan sosial.

Pentingnya dakwah bil hikmah pada masa kini khususnya bagi generasi millenial bertujuan untuk:

1. Memahami agama

Pemahaman yang baik terhadap nilai-nilai agama akan membawa seseorang kepada kematangan berfikir dan kemurnian hati yang baik. Nilai-nilai agama akan memberikan pandangan hidup atas semua bentuk perilaku manusia. Adanya syari'at dan hukum yang mengatur menjadikan manusia tidak semena-mena dalam melakukan sesuatu. Ada nilai yang menjadi pembeda dengan nilai-nilai yang hanya bersifat kebiasaan saja. Agama diturunkan untuk dipahami dan dijalankan sesuai dengan syari'atnya. Ada dampak sebab dan akibat yang menyertai segala bentuk perbuatan manusia. Generasi millenial harus terus belajar dan memahami nilai-nilai agama yang dianutnya. Oleh karena itu dakwah yang humanis dan menarik diharapkan mampu menjadi penarik minat mereka terhadap agama.

2. Mengambil faedah dari pengalaman 
Belajar dari pengalaman merupakan kata-kata yang sering didengar dan diucapkan. Namun, terkadang dalam penerapannya seringkali manusia lupa jika ia pernah melakukan sebuah perbuatan sebelumnya. Kelengaan terhadap sebuah kondisi, banyaknya orang yang melakukan seringkali membuat kita juga turut melakukan hal yang sama. meskipun sudah banyak contoh dampak dari kejadian tersebut. Memetik hikmah dari sebuah pengalaman menjadikan generasi millenial akan berhatihati dalam melakukan tindakan dan pengambilan keputusan.

3. Belajar dari kesalahan

Generasi millenial yang saat ini masih sangat muda terkadang tanpa sadar selalu meniru atau mengulang kesalahan yang pernah dilakukannya. Jiwa muda mereka melahirkan rasa keegoisan dan kesombongan terhadap sebuah hal. Merasa pendapatnya paling benar dan menganggap generasi sebelumnya sebagai generasi yang kaku, tidak memahami perkembangan dan trend kehidupan masa kini.

4. Waspada agar tidak terjerumus dalam kesalahan

Sikap kehati-hatian seperti rambu-rambu yang akan mengatur perbuatan seseorang. Ada kalanya sesuatu yang terlihat baik sesungguhnya menyimpan rahasia keburukan yang jika dilakukan akan menyebabkan kita melakukan sebuah kesalahan.

\section{Kesimpulan}

Generasi millenial yang saat ini berada pada masa produktif sangat disorot segala tindakannya karena dianggap cukup berbeda dengan generasi sebelumnya. Kehidupan generasi millenial yang tidak terlepas dari penggunaan alatalat komunikasi dan teknologi mempunyai ciri khas dan mengakibatkan terjadinya perubahan-perubahan dalam sendisendi kehidupan di masyarakat. Perubahan-perubahan yang terjadi ada yang bersifat positif ada juga yang bersifat negatif. perubahan positif yang dibawa generasi millenial dianggap sebagai sebuah kemajuan, sedangkan perubahan yang bersifat negatif perlu diantisipasi dan membutuhkan solusi. Salah satu solusi yang ditawarkan yaitu metode dakwah bil hikmah. mencegah manusia dari perbuatan zalim. Dakwah bil hikmah yang dilakukan Nabi Muhammad, dalam QS. Al-Nahl, 16:125, yaitu memeberikan teladan yang terbaik dalam sikap dan perilaku, dengan sesalu sopan santun kepada siapapun. Hal ini kemudian diistilahkan dengan akhlaqul-kharimah. Beliau mendapat predikat dari langit "uswatun hasanah" (baca QS. Al-Ahzab, 33:21) yang bermakna teladan terbaik dan terpuji.

Pendekatan agama atau dakwah terhadap generasi millennial juga harus dilakukan melalui pemanfaatan media-media komunikasi karena pengguna terbanyak adalah generasi millennial. Dakwah melalui pemanfaatan media komunikasi dan teknologi akan lebih 
mudah mencapai sasaran karena beda generasi beda pula cara pendekatan yang digunakan. Ada empat cara agar seseorang memperoleh hikmah diantaranya yaitu: memahami agama, mengambil faedah dari pengalaman, belajar dari kesalahan, waspada agar tidak terjerumus dalam kesalahan.

\section{Daftar Kepustakaan}

Abdullah, (2015), Ilmu Dakwah, Kajian Ontologi, Epistimologi, Aksiologi dan Aplikasi Dakwah, Bandung: Citapustaka Media.

Abū al-Husain Ahmad ibn Fāris ibn Zakariyā, (1998), Mu'jam al-Muqāyis fì al-Lughah, Cet. II: Bairut: Dār al-Fikr li al-Tarbiyah wa al-Nasyr wa al-Tauzī,

Al-Khazandar,
Muhammad alhikmah,
mohammad iqbal alghazali, isalm
house.com, 2009/1430.

Aziz, Ali, (2004), Ilmu Dakwah, Jakarta: Kencana Prenada Media Group.

Bastomi, Hasan, (2016), Dakwah Bil Hikmah Sebagai Pola Pengembangan Sosial Keagamaan Masyarakat, Jurnal Ilmu Dakwah, Vol. 36(2) 2016 Eissn 2581-236x.

Departemen Pendidikan dan Kebudayaan, Kamus Besar Bahasa Indonesia Jakarta: Balai Pustaka

Ibnu Asyūr, al-Taḥrīr wa alTanwīr, (1996), Juz 2, Bairut: Dār alFikr.
Muhyidin, Asep, (2002), Dakwah Dalam Perspektif AlQura'an: Studi Kritis Atas Visi, Misi dan Wawasan, Bandung: Pustaka Setia.

Muḥammad Fuād 'Abd alBāqī, (1992)Mu'jam Mufahras li alFāz al-Qur'ān al-Karīm, Bairut: Dār al-Fikr.

Rahmat, Jalaluddin, (1990), Ilmu Dakwah dan Kaitannya Dengan Ilmu-Ilmu Lain, Semarang :Seminar.

Islam $\overline{\text { Aktual }} \overline{\text { Cet. IX, Bandung: }}$ Mizan.

Tahir, Muhyiddin, Hikmah dalam Perspekt Al-Qur'an Hunafa: Jurnal Studia Islamika, PPs UIN Alauddin Makassar, Jl. Sultan Alauddin 23 Makassar.

Salmadanis, (2014), Standar Kompetensi Pelaku Dakwah, Sumatra Barat: Imam Bonjol Pres.

Saputra, Wahidin, (2012), Pengantar Ilmu Dakwah, Jakarta: Raja Gerafindo Persada.

Shaifuddin, Asep, Sheh Sulhawi Rubba,(2011), Fikih Ibadah Safari ke Baitullah, Surabaya: Garisi.

Syulrianto, Dakwah Kultural: Kasus Penyebaran Islam di Jawa, Fakultas Dakwah IAIN Sunan Kalijaga, (Jurnal Dakwah No, 4 Januari-Juni 2002)

Syihāb al-Dīn Said Mạ̣mūd al-Alūsī al-Baghdādī, (2001), Rù halMa'ānī fì Tafsìr al-Qur'ān al-Az̄ìm 
wa al-Sab' al-Mas̄ān̄i, Bairut: Dār alKutub al-Ilmiyah.

Saputara, Wahidin, (2011), Pengantar Ilmu Dakwah, Jakarta.: Rajawali Press.

Zain al-Dīn Abī al-Faraj ibn Rajāb al-Hambalī, Fath al-Bāri' bi Syarh al-Bukhāri, Jilid 1 (Madinah : Maktabat al-Ghuraba).

\section{Website:}

$\underline{\text { http://rumahmillennials.com/s }}$ iapa-itu-generasi millenials/\#.XK9HW0gxXMw, diunduh 11 April 2019.

http://pontianak.tribunnews.c om/tag/justiceaudrey?url=2019/04/1 1/benarkah-terjadi-penusukan-alatkelamin-di-kasus-audrey-pontianakfakta-fakta-ini-menjawabnya, diunduh tanggal 13 April 2019, 04.06 WIB 